\title{
Taking into Account the Complex Nature and the Intrinsic Parameters of Agro-Food Products during Convective Drying
}

\author{
Ganame Abdou-Salam, Ouoba Kondia Honore*, Zougmore François \\ Laboratoire des matériaux et Environnement (LA.M.E.), Unité de Formation et de Recherche en Sciences Exactes et Appliquée \\ (UFR/SEA), Université de Ouaga I, Joseph KI-ZERBO, Ouagadougou, Burkina Faso \\ Email: ${ }^{*}$ ouobakahonore@yahoo.fr
}

How to cite this paper: Abdou-Salam, G., Honore, O.K. and François, Z. (2020) Taking into Account the Complex Nature and the Intrinsic Parameters of Agro-Food Products during Convective Drying. Journal of Biophysical Chemistry, 11, 1-13. https://doi.org/10.4236/jbpc.2020.111001

Received: January 2, 2020

Accepted: February 24, 2020

Published: February 27, 2020

Copyright ( 2020 by author(s) and Scientific Research Publishing Inc. This work is licensed under the Creative Commons Attribution International License (CC BY 4.0).

http://creativecommons.org/licenses/by/4.0/

\begin{abstract}
In this paper, we perform experiments on the drying of widely consumed food products in Africa. Tomatoes and peppers are considered as products with a complex structure. Zucchini, cucumber, eggplant and cabbages are the other products used in these drying experiments, having different intrinsic parameters. Most food products have three components, namely skin, flesh containing seeds and the central spongy structure, that do not have the same behavior during their convective drying. Skin is the component that significantly reduces drying while the flesh is easy to dry. By drying the samples considering their intrinsic parameters, one quickly realizes the complex nature of mass and heat transfers during the drying of biological products.
\end{abstract}

\section{Keywords}

Skin, Flesh, Structure, Convective Drying, Agri-Food Products

\section{Introduction}

Tomato (Solanum lycopersicum), cabbage (Brassica oleracea var capitata), eggplant (Solanum melongena), cucumber (Cucumis sativus), pepper (Capsicum annuum Group), onion (Allium cepa) and zucchini (Cucurbita pepo L) are the most consumed products in Africa and Asia [1] [2] [3]. They consist for the most part of three components namely skin, seeds and a spongy core material. For the preservation of large production [4], consumers proceed with their drying. On a family scale, products are more often cut into random shapes and sizes [5] before being exposed for drying (Figure 1). Cutting is usually done manually, without measurements [6], and from one dryer to another, the size and shape vary. 


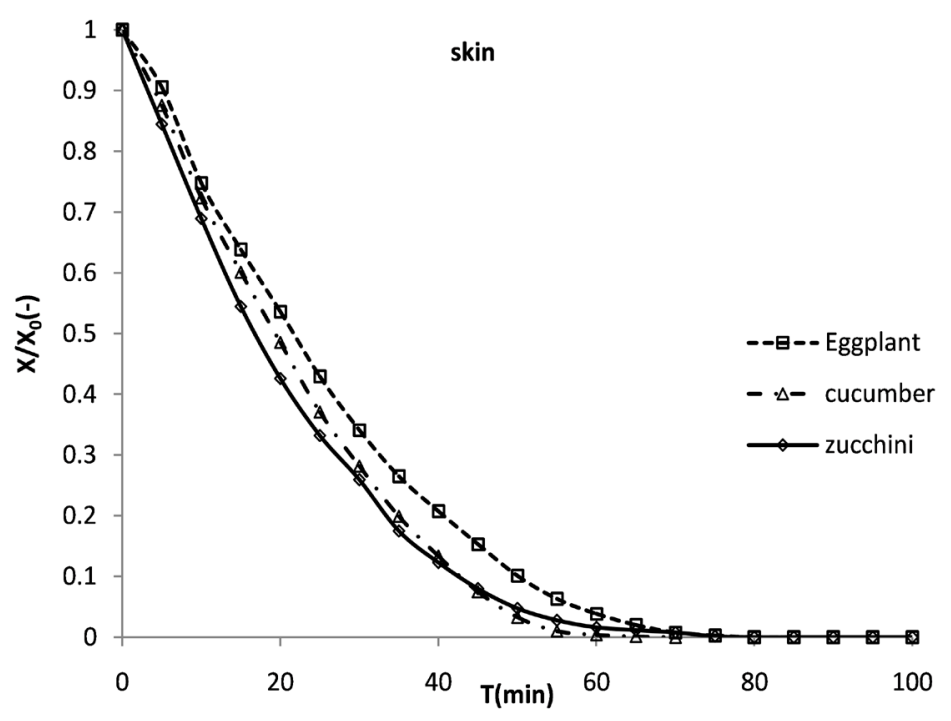

Figure 1. Comparative study of convective drying of zucchini, eggplant and cucumber skin.

The poor mastery of drying phenomena leads to finished products of dubious quality. The mastery of the drying of food products cannot succeed without the control of drying phenomena of its constituents taken separately [7]. Thus, one can obtain a dry product of acceptable quality [8], which takes into account its nutrition appreciation as well as its therapeutic virtues, before thinking about its conservation [5].

In this work, we characterize both the convective drying of the different constituent parts of the aforementioned food products taken separately in order to find the part that optimizes drying. For this, the skin and the flesh are considered in order to estimate their behavior in the face of drying. We also consider the structure of food products during this work. Also, we will examine the influence of the initial hydric states on the convective drying time of products.

\section{Materials and Methods}

\subsection{Organic Products}

All of these food products used in this study, namely Tomato, Pepper, Cabbage, Zucchini, Eggplant and Cucumber, are purchased at a local market in Bobo-Dioulasso, Burkina Faso. Their Characterization was done by taking into account their different constituents taken separately.

Cucumber, eggplant and zucchini have similar structures. There have grains fixed by a spongy material and all wrapped in a smooth skin.

The pepper and the tomato consist of a thick envelope and all wrapped in a thin and smooth skin. The interior is subdivided into a compartment containing grains. Noteworthy difference is between tomato and pepper in the sense that the pepper filled with gas these compartments, while the tomato fills them with liquid. 
Cabbage and onion have laminar structures. For the onion, we will consider it has a uniform structure. As for cabbage, it starts from a main rib, which divides into secondary ribs that mesh the whole leaf.

This present work considers the drying of these different products by considering this complex constitution of the product.

\subsection{Sample Preparation}

The different products bought at the local market were brought to the laboratory GERME \& TI of University Nazi Boni of Bobo-Dioulasso, Burkina Faso. Immediately, without storing them, they are washed and cleanly wiped to remove any contaminant that could influence their drying. Indeed, mud, rotten fruit juice and other gelatinous secretions often envelop the product, as sellers deposit them in a pile of mixed products. Each product is cut according to the part that holds our attention. This allows us to take into account the part of the cut in the estimation of the parameters and to observe the influence of that part in the drying to reach at an acceptable drying quality. Firstly, the products are cut in such a way as to consider their constituents: skin and flesh (for zucchini, eggplant and cucumber), for cabbage it is the main rib, the secondary rib and the leaves which are considered. As for tomato and pepper, it is the flesh that is taken into account and finally, samples of slices of onion and cabbage.

Using a stainless knife, samples 5 to $10 \mathrm{~mm}$ long were cut.

For each type, we have at least three samples to compare and average their behavior.

\subsection{Experimental Procedures}

In order to understand the importance of the part of the cut and the contribution of the constituents of the products used, we set the external parameters such as the temperature at $80^{\circ} \mathrm{C}$. A convection dryer WTF BINDER) was used for drying characterization. Each part of the product is cut out, the constituents separated and dried at $80^{\circ} \mathrm{C}$. During drying, each sample is regularly removed from the oven, the mass of the sample is determined with a SARTORIUS scale, $0.001 \mathrm{~g}$ of precision, France), and the dimensions measured using a digital display micrometer MITUTOYO, Japan, $2 \times 10^{-5} \mathrm{~m}$ precision). The dry mass of the product as well as that of its constituents were evaluated by drying the product in an oven set at $80^{\circ} \mathrm{C}$ for 24 hours [5]-[10].

\section{Data Analysis}

\subsection{Water Content}

The initial water content of the different parts of the products and their constituents is determined by the relation (1):

$$
X_{0}=\frac{m_{e}}{m_{s}}=\frac{m_{0}-m_{s}}{m_{s}}
$$


where $m_{e}(\mathrm{Kg})$ the water mass initially contained in the product, $m_{0}(\mathrm{Kg})$ the initial mass of the sample and $m_{s}(\mathrm{Kg})$ the mass of the dried sample.

The water content at each instant $\mathrm{t}$ of the drying is $X(t)\left(\mathrm{kge} \cdot \mathrm{kg}^{-1} \mathrm{~ms}\right)$ determined from the experimental data by the formula (2):

$$
X(t)=\frac{m(t)-m_{s}}{m_{s}}
$$

where $m(t)(\mathrm{Kg})$ is the mass of the sample at each instant $t(\mathrm{~s})$ of drying. The drying kinetics are plotted by the variation of $X(t)$ as a function of the drying time. The critical water content is estimated by the method of tangents at the origin. It consists of drawing the tangent to the original drying kinetics curve as reported by Dissa et al. [11]. The critical water content is the take-off point between the tangent and the curve.

\subsection{Kinetic Establishment}

To establish the drying curves, $X(t)-t$ in this work, we calculate using the Microsoft Excel software the water content of each sample from the regular recordings of the masses of the sample at intervals of time during the drying process. We then normalize the instantaneous water content by dividing it by the initial water content, $X / X_{0}$. This has the advantage of having the same initial point for all the curves, i.e. $X_{0} / X_{0}=1$ at the initial moment, in other words, at the initial moment, all the samples had $100 \%$ of their water.

Then these water contents decrease over time and we examine the drying efficiency by the relative position of the different curves. For a given time, the sample loses more water if its normed water content is low, which results in a curve closer to the abscissa axes $(t)$.

Another possibility of assessing the drying is the determination of the diffusion coefficients. They are obtained in solvent the second law of Fick according to the form of the sample [12] [13]. For this, the experimental results can be analyzed using the diffusion equation of Fick, developed by Crank 1975) [14] [15] [16]. Assuming that the transfers are one-dimensional, the initially uniform water content in the product, without contraction of the solid matter and a long diffusion time [17] [18], the analytical solution of the Fick equation is given by the equation Equations (3)-(5) for the cylindrical form [19]:

- Cylindrical shape:

$$
M R=\frac{X_{t}-X_{e q}}{X_{o}-X_{e q}}=\frac{4}{\beta^{2}} \exp \left(-\frac{\beta^{2} D_{e f f} t}{r_{c}^{2}}\right)
$$

- Spherical shape:

$$
M R=\frac{X_{t}-X_{e q}}{X_{o}-X_{e q}}=\frac{6}{\pi^{2}} \exp \left(-\frac{\pi^{2} D_{e f f} t}{r_{S}^{2}}\right)
$$

- Infinite plate: 


$$
M R=\frac{X_{t}-X_{e q}}{X_{0}-X_{e q}}=\frac{8}{\pi^{2}} \exp \left(-\frac{\pi}{4} \frac{D_{e f f} t}{L^{2}}\right)
$$

In Equations (3)-(5), MR the water content ratio, $X_{t}\left(\mathrm{kge} \cdot \mathrm{kg}^{-1} \mathrm{~ms}\right)$ the average water content of the product, $X_{0}\left(\mathrm{kge} \mathrm{kg}^{-1} \mathrm{~ms}\right)$ its initial water content, $X_{e q}$ (kge $\cdot \mathrm{kg}^{-1} \mathrm{~ms}$ ) equilibrium water content, $D_{\text {eff }}\left(\mathrm{m}^{2} \cdot \mathrm{s}^{-1}\right)$ is the effective scattering coefficient, $r_{c}, r_{s}(\mathrm{~m})$ are respectively the radius of the cylinder and the sphere, $\mathrm{L}$ $(\mathrm{m})$ the characteristic length of the plate and $t(s)$ the drying time.

The diffusion coefficients are generally determined by plotting the relationship in terms of $\ln (M R)$ as a function of the drying time $t$. Diffusion coefficients are determined by the slope of $\ln (\mathrm{MR})$ as a function of time in the form of a straight line. Indeed, the equations Equations (3)-(5) [20] can simply be in the form Equation (6) [21] [22]:

$$
\ln (M R)=A-B \cdot t
$$

$A$ and $B$ are constants deduced graphically from the line. $\beta$ is calculated from the value of $A$ and reintroduced into $B$ for the determination of the diffusion coefficient.

Some authors have shown that $D_{\text {eff }}$ depends on the temperature. This dependence is linear as a function of the inverse of the temperature $1 / T$ [11] [23] [24] [25] [26]. It comes in the form called Arrhenius dependence:

$$
D_{\text {eff }}=D_{0} \exp \left(-\frac{E_{a}}{R \cdot T}\right)
$$

where $D_{0}\left(\mathrm{~m}^{2} / \mathrm{s}\right)$, is the pre-exponential factor of the Arrhenius equation. $E_{a}$ $(\mathrm{kJ} / \mathrm{mol})$ is the activation energy, $T(K)$ is the temperature of the sample, $R$ $(\mathrm{kJ} / \mathrm{mol} \cdot \mathrm{K})$ is the constant of the perfect gases. In order to see the influence of the temperature on the diffusion coefficient, we draw $D_{\text {eff }}$ according to the inverse of the temperature 1/T[27] [28] [29].

\section{Results and Discussions}

\subsection{Characterization of the Dried Product}

Table 1 summarizes the initial water content and the drying times of the different samples used in this work. Note that for repetition, each point of a curve is the average of at least three tests.

We highlight the non-uniformity of the water content in the material submitted to the tests. This interpellates the actors on the ground to note that for the same agri-food product, the water content can vary from one sample to another. For example, for zucchini skin, one of the samples has a water content of 32 $\mathrm{kg} / \mathrm{kg}$ against the lowest of $20.04 \mathrm{~kg} / \mathrm{kg}$.

For products like eggplant and zucchini, this work shows that skins have a relatively higher water content than flesh. In fact, these products have respective water contents, for their skin of 11.21 and 28.20 and for their flesh of 9.76 and $21.13 \mathrm{~kg} / \mathrm{kg}$. The results on cucumber show the opposite. Its flesh has a water 
Table 1. Initial water content and drying time of dried products.

\begin{tabular}{|c|c|c|c|c|c|c|c|c|c|c|c|c|}
\hline Physical size & $\begin{array}{l}\text { cucumber } \\
\text { skin }\end{array}$ & $\begin{array}{l}\text { cucumber } \\
\text { flesh }\end{array}$ & $\begin{array}{l}\text { eggplant } \\
\text { skin }\end{array}$ & $\begin{array}{l}\text { eggplant } \\
\text { flesh }\end{array}$ & $\begin{array}{l}\text { zucchini } \\
\text { skin }\end{array}$ & $\begin{array}{l}\text { Zucchini } \\
\text { flesh }\end{array}$ & $\begin{array}{c}\text { cabbage } \\
\text { leaf }\end{array}$ & $\begin{array}{c}\text { secondary } \\
\text { rib } \\
\text { cabbage }\end{array}$ & $\begin{array}{l}\text { main rib } \\
\text { cabbage }\end{array}$ & onion & pepper & tomato \\
\hline $\begin{array}{c}\text { Sample } 1 \\
\mathrm{X}_{01}(\mathrm{Kg} / \mathrm{Kg})\end{array}$ & 19.92 & 26.96 & 11.5 & 9.9 & 32 & 22.38 & 5.62 & 11.31 & 10.25 & 10.97 & 10.58 & 13.47 \\
\hline $\begin{array}{c}\text { Sample } 2 \\
\mathrm{X}_{02}(\mathrm{Kg} / \mathrm{Kg})\end{array}$ & 19.24 & 27.54 & 11.27 & 9.93 & 22.76 & 20.96 & 3.83 & 10.85 & 9.63 & 10.67 & 10.86 & 13.56 \\
\hline $\begin{array}{c}\text { Sample } 3 \\
\mathrm{X}_{03}(\mathrm{Kg} / \mathrm{Kg})\end{array}$ & 20.36 & 27.45 & 10.86 & 9.45 & 29.85 & 20.04 & 4.69 & 11.12 & 9.99 & 12.25 & 10.53 & 13.28 \\
\hline $\mathrm{X}_{0 \text { moy }}(\mathrm{Kg} / \mathrm{Kg})$ & 19.84 & 27.32 & 11.21 & 9.76 & 28.2 & 21.13 & 4.71 & 11.09 & 9.96 & 11.3 & 10.66 & 13.44 \\
\hline $\begin{array}{l}\text { Deviation } \\
(\mathrm{Kg} / \mathrm{Kg})\end{array}$ & 0.4 & 0.24 & 0.23 & 0.21 & 3.63 & 0.84 & 0.6 & 0.16 & 0.22 & 0.64 & 0.14 & 0.1 \\
\hline $\begin{array}{l}\text { Average drying } \\
\text { time (mn) }\end{array}$ & 58 & 70 & 75 & 60 & 80 & 65 & 38 & 90 & 75 & 105 & 100 & 100 \\
\hline
\end{tabular}

content higher than that of its skin, 27.32 for the flesh of cucumber against 19.84 $\mathrm{kg} / \mathrm{kg}$ for its skin.

In this same order, the skin of the cucumber dries faster than its flesh, $58 \mathrm{~min}$ against $70 \mathrm{~min}$ as time taken for the drying of the skin and the flesh of the cucumber. Eggplant and zucchini skins take about $75 \mathrm{~min}$ and $80 \mathrm{~min}$ respectively for drying. As for their flesh, we note a drying time of 60 and $65 \mathrm{~min}$ respectively. These results seem to show that the higher the water content of a product, it dries slowly.

Cabbage is considered in this work as a non-homogeneous product. Secondary ribs mesh the entire leaf, symmetrically with respect to a main rib. These different parts namely the main rib, the secondary rib and the leaf respectively have 9.96, 11.09 and $4.71 \mathrm{~kg} / \mathrm{kg}$ as a value of their average water content and respectively 75.90 and $38 \mathrm{~min}$ for their complete drying. For cabbage too, the drying time is classified according to the initial water content. The water content of the onion is slightly higher than that of the secondary rib of cabbage, 11.3 against $11.09 \mathrm{~kg} / \mathrm{kg}$ and $105 \mathrm{~min}$ for drying.

On the other hand, pepper and tomato all take about 100 minutes to dry, although their water content is different, respectively 10.66 and $13.44 \mathrm{~kg} / \mathrm{kg}$.

This paragraph exposes the complex nature of agri-food product drying modeling [26].

\subsection{Resistance to the Transfer of Skins of Organic Products}

Traditional drying in Africa is generally practiced by women with different sizes and shapes of cutting. There is no question of worrying about the influence of any part of the product to be dried. In this paper, we would like to understand if transfers will be better done by controlling the behavior of product components. 
We focus here on the study of transfers at the outer shell of the product. The skins of the three different products were dried to obtain the curves of Figure 1. The measurements were carried out three times for the reproducibility of the results for the convective drying at $80^{\circ} \mathrm{C}$. Thus, each point is the average of three measurements. Figure 1 shows that the cut made of the zucchini skin dries slightly better than the skin of the cucumber and eggplant.

The critical states of these different forms of cutting are summarized in Table 2. The results show that cutting the skin of cucumber quickly reaches its critical state as skin samples from eggplant and zucchini.

The $10 \mathrm{~mm}$ thick slice samples reach their final drying times of approximately 70, 65 and 60 min respectively for eggplant, cucumber and zucchini. Their initial water content in the same order is equal to 5.85 .6 .51 and $4.62 \mathrm{Kg} / \mathrm{kg}$ respectively. Here, have noted that it is not the initial water content that governs the state of drying; but the very nature of the product. The critical time and the relative water content for cutting the cucumber skin are respectively $35 \mathrm{~min}$ and 1.95 $\mathrm{Kg} / \mathrm{kg}$. As for the skin of eggplant, these values are $50 \mathrm{~min}$ and $3.8 \mathrm{~kg} / \mathrm{kg}$. For zucchini skin, these values are respectively $42 \mathrm{~min}$ and $2.91 \mathrm{Kg} / \mathrm{kg}$.

\subsection{Flesh Behavior during Convective Drying}

By drying the zucchini, eggplant and cucumber samples taken separately at $80^{\circ} \mathrm{C}$, the results showed that they do not have the same behavior when drying (Figure 2). Each drying kinetics curve was repeated three times to verify the repetability. The flesh of the zucchini dries faster than that of the eggplant. The flesh of the cucumber of these three products: zucchini flesh, eggplant flesh and cucumber flesh, cucumber one is more resistant to transfer during drying. We observe that at $80^{\circ} \mathrm{C}$ with free convection, the zucchini puts about $60 \mathrm{~min}$ of drying time; eggplant $65 \mathrm{~min}$ and cucumber $75 \mathrm{~min}$. This ease of zucchini drying compared to eggplant and cucumber may be of interest for its therapeutic applications, where low temperatures and reduced drying time are required to maintain the chemical elements. In addition, on an industrial scale, the difference between the drying times of different products must be taken into account, in order to maintain the nutritional quality of each before drying.

Comparing these results with those of skin behavior, a paradox presents itself in three situations:

- The slices of 10 minutes skin and flesh thickness of the zucchini have the same behavior when drying and take 60 minutes to dry;

Table 2. Critical time and critical water content of the skin of cucumber, eggplant and zucchini.

\begin{tabular}{lccccc}
\hline & $X_{0}(\mathrm{Kg} / \mathrm{Kg})$ & $X_{c r}(\mathrm{Kg} / \mathrm{Kg})$ & $X_{c r} / X_{0}(-)$ & $t_{c r}(\mathrm{~min})$ & $t_{f}(\mathrm{~min})$ \\
\hline cucumber skin & 6.51 & 1.95 & 0.15 & 35 & 65 \\
Eggplant skin & 5.85 & 3.8 & 0.14 & 50 & 70 \\
Zucchini skin & 4.62 & 2.91 & 0.12 & 42 & 60 \\
\hline
\end{tabular}




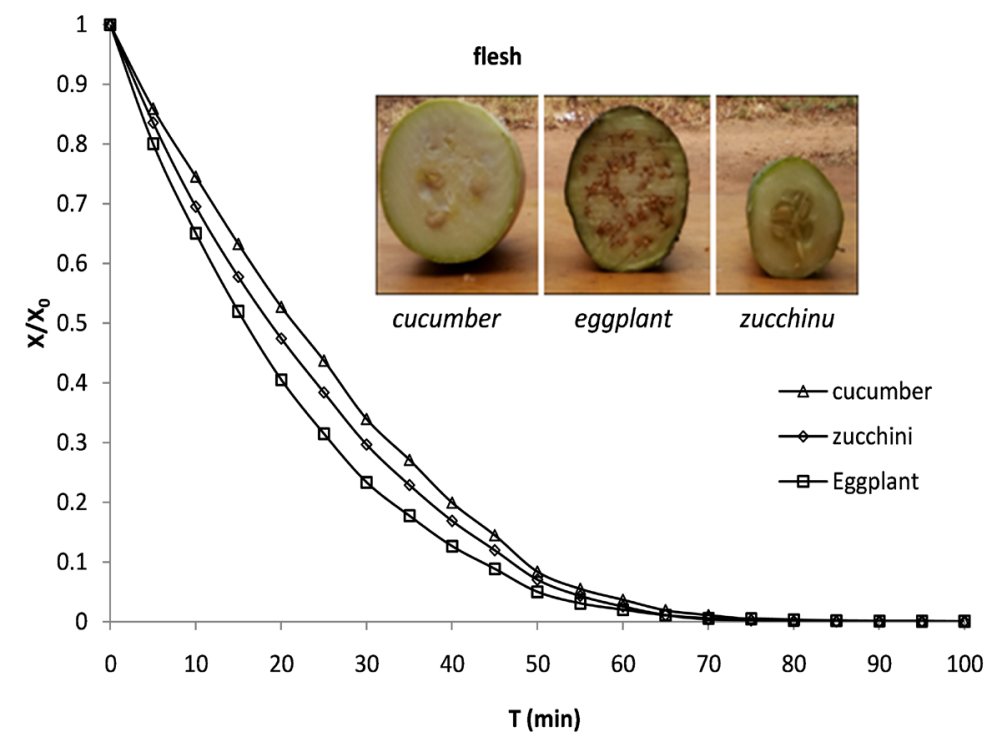

Figure 2. Three products flesh behavior during convective drying curves. $T=$ $80^{\circ} \mathrm{C}$ : zucchini, eggplant and cucumber.

- The flesh of the eggplant dries more pane than its skin. Indeed, at $80^{\circ} \mathrm{C}$, the two samples, namely skin and flesh. 10 minutes thick respectively 70 min and 65 min respectively for their complete drying.

- As for cucumber, its skin dries faster than its flesh is a drying time of $65 \mathrm{~min}$ and 75 min respectively.

From these results it can be concluded that the control of the drying of agri-food products is complex. For very specific uses such as the medicinal field or as a dietary supplement, it would be desirable to take into account all these aspects.

\subsection{Non-Uniform Nature of the Material}

In this section, we compare the different behaviors of different parts of the cabbage namely the main rib, the secondary rib and the leaf. To have the same dimensions, we were forced to take samples of $5 \mathrm{mn}$ of sides. Drying the different parts of the cabbage, we find that the leaf dries faster than the main rib and it also dries faster than the secondary rib. The different parts of the cabbage dry differently. The leaf reaches its critical content faster than the other constituents.

These notable differences in behavior (Figure 3) will affect the drying of whole cabbage. Either it leads to a dried product where the ribs are not dry enough, which will contribute to the development of mold during storage, or over-dried leaves without nutritional values such as vitamins or other volatile components and even the deterioration of appearance of cabbage.

\subsection{Drying of Lamellar Structures}

By drying the onion slices and a whole cabbage leaf with all the ribs, it is found that the cabbage leaves dry faster than the onion slices. They are identical slats with several cutting samples that are subjected to a temperature of $80^{\circ} \mathrm{C}$. The 


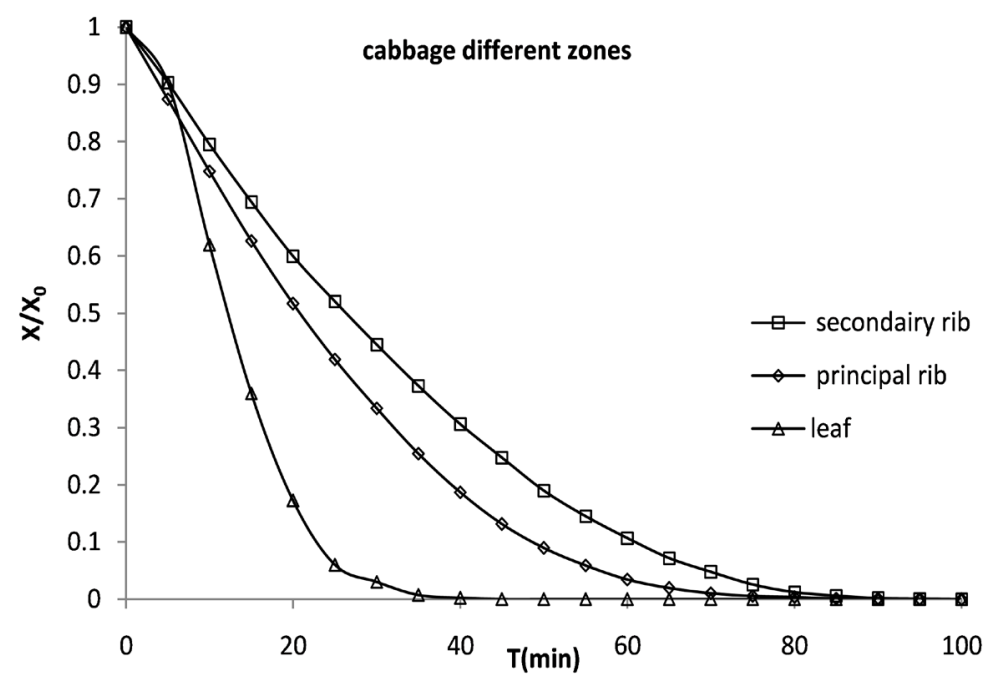

Figure 3. Influence of the three parts of cabbage on its convective drying. $T$ $=80^{\circ} \mathrm{C}$.

results showed that they do not have the same behavior when drying (Figure 4). The drying time of onion and cabbage are $110 \mathrm{~min}$ and $40 \mathrm{~min}$ respectively. This gap is huge for similar structures. Indeed, the onion takes about three times longer than the cabbage for its convective drying at $80^{\circ} \mathrm{C}$. The water content for onion and cabbage, respectively is $11.30 \mathrm{~kg} / \mathrm{kg}$ and $9.65 \mathrm{~kg} / \mathrm{kg}$.

\subsection{Tomato and Pepper}

These two vegetables have a similar structure. They all contain seeds enclosed by a thick envelope whose exterior is a waterproof and smooth skin.

The difference is that the tomato contains juice unlike pepper contained in empty spaces containing gas in place of a liquid.

We compare here, their resistance to transfers during convective drying. $80^{\circ} \mathrm{C}$. The results of Figure 5 show that the strips of $1 \times 2 \mathrm{~cm}$ cut in these different vegetables have very similar strengths. The evolution curve of the normed water content $X / X_{0}-t$ is almost linear. This proves that the water contained in these materials is almost free and evaporates freely.

\section{Conclusions}

It will be remembered from this work that the control of the drying of agro-food products is complex. For very specific uses such as the medicinal field or as a dietary supplement, it would be desirable to take into account all these aspects.

Based on products commonly consumed in Africa, the results challenge the actors on the ground to consider for the same agri-food product, the difference in water content from one sample to another.

By comparing the behavioral results of skins and flesh, three situations arise:

- The slices of 10 minutes skin and flesh thickness of the zucchini have the same behavior when drying and take 60 minutes to dry; 


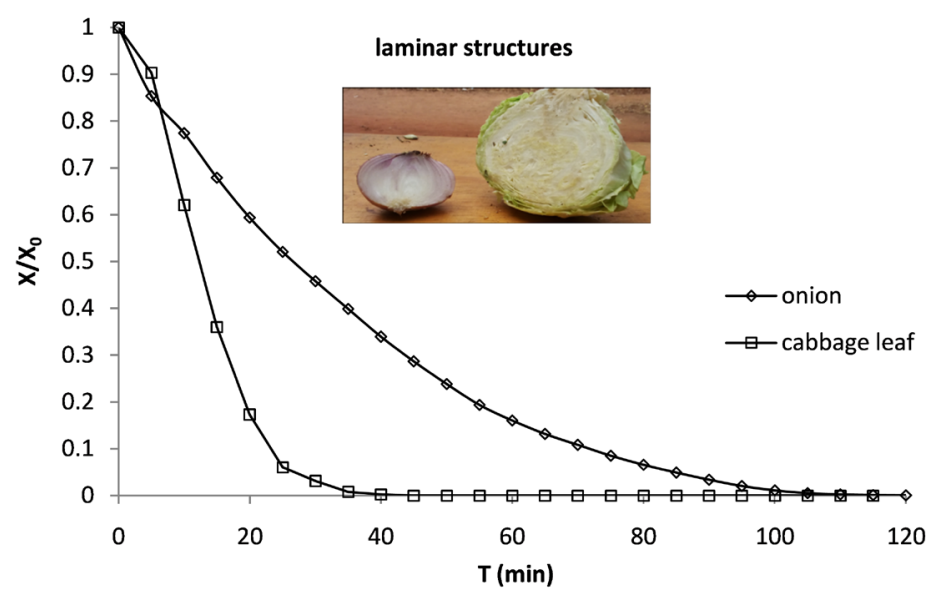

Figure 4. Comparative study of lamellar structures: onion and cabbage.

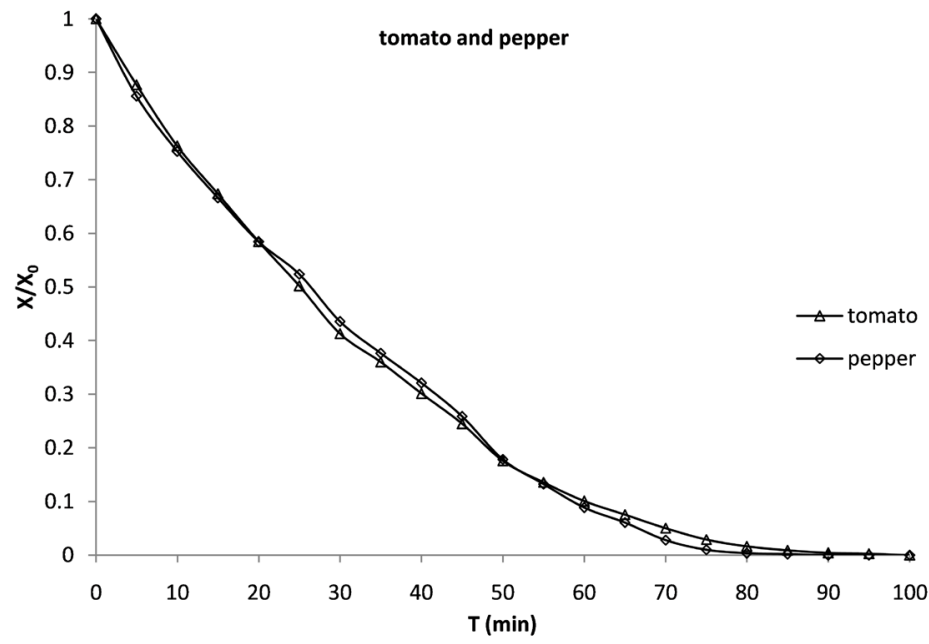

Figure 5. Comparative study of similar structures of tomato and pepper.

- The flesh of the eggplant dries more pane than its skin. Indeed, at $80^{\circ} \mathrm{C}$, the two samples, namely skin and flesh. 10 minutes thick respectively $70 \mathrm{~min}$ and 65 min respectively for their complete drying.

- As for cucumber, its skin dries faster than its flesh is a drying time of $65 \mathrm{~min}$ and 75 min respectively.

For the same product as cabbage, the water content varies from one area to another. And the drying of an entire product without taking into account its different structures would not result in a dry product of good quality.

These results could be taken into account when drying agri-food products, especially for certain therapeutic applications where chemical elements (vitamins or thermosensitive and volatile elements) require a short drying time and a low temperature.

\section{Conflicts of Interest}

The authors declare no conflicts of interest regarding the publication of this paper. 


\section{References}

[1] Camciuc, M., Deplagne, M., Vilarem, G. and Gaset, A. (1998) Okra-Abelmoschus esculentus L. (Moench.) a Crop with Economic Potential for Set aside Acreage in France. Industrial Crops and Products, 7, 257-264. https://doi.org/10.1016/S0926-6690(97)00056-3

[2] Avallonea, S., Tiemtorea, T.W.E., Rivierb, C. and Trècheb, S. (2008) Nutritional Value of Six Multi-Ingredient Sauces from Burkina Faso. Journal of Food Composition and Analysis, 21, 553-558. https://doi.org/10.1016/j.jfca.2008.04.012

[3] Sengkhamparn, N., Sagis, L.M.C., Renko de Vries, A., Henk Schols, H.A., Sajjaanantakul, T., Alphons, G.J. and Voragen, A.G.J. (2008) Physicochemical properties of Pectins from Ocra Abelmoschus esculentus L. Moench. Food Hydrocolloids, 24, 35-41. https://doi.org/10.1016/j.foodhyd.2009.07.007

[4] FAOSTAT (Food and Agricultural Organization of the United Nations) (2008) On-Line and Multilingual Database Currently Covering International Statistics. http://faostat.fao.org/foastat/

[5] Ouoba, K. (2013) Honoré. Séchage des produits agroalimentaires: Influence de la taille. De la forme et de la découpe. Thèse de doctorat. Université de Ouagadougou.

[6] Kordylas, J.M. (1991) Processing and Preservation of Tropical and Subtropical Foods. Macmillan Education Ltd., London, UK.

[7] Honoré Ouoba, K. and Desmorieux, H. (2010) François Zougmore et Bétaboalé NAONCaractérisation du séchage convectif du gombo. influence de la découpe et de ses constituants. Afrique SCIENCE, 6, 37-48. http://www.afriquescience.info

[8] Ouoba, K.H., Zougmore, F., Naon, B. and Desmorieux, H. (2012) Profils des teneurs en eau de la patate douce Durant son Séchage Convectif. Revue du CAMES-Série A, 13, 201-205.

[9] Adorn, K.K., Dzogbefia, V.P., Ellis, W. and Simpsor, B.K. (1996) Solar Drying of Ocra-Effects of Selected Package Materials on Storage Stability. Food Research International, 29, 589-593. https://doi.org/10.1016/S0963-9969(96)00076-2

[10] AOAC (Association of official Chemists) (1990) Official Methods of Analysis No. 934-06. Washington DC.

[11] Dissa, A.O., Desmorieux, H., Savadogo, P.W., Segda, B.G. and Koulidiati, J. (2010) Shrinkage. Porosity and Density Behaviour during Convective Drying of Spirulina. Journal of Food Engineering, 97, 410-418. https://doi.org/10.1016/j.jfoodeng.2009.10.036

[12] Wang, N. and Brennan, J.G. (1992) Effect of Water Binding on the Drying Behavior of Potato. Drying, 92, 1350-1359.

[13] Sablani, S., Rahman, S. and Al-Habsi, N. (2000) Moisture Diffusivity in Foods an Overview. In: Mujumdar, A.S., Ed., Drying Technology in Agriculture and Food Sciences Enfield, Wiley, New York, 35-59.

[14] Saravacos, G.D. and Maroulis, Z.B. (2001) Transport Properties of Foods. Marcel Dekker, New York.

[15] Hashemi, G., Mowla, D. and Kazemeini, M. (2009) Moisture Diffusivity and Shrinkage of Broad Beans during Bulk Dry in an Inert Medium Fluidized Bed Dryer Assisted by Dielectric Heating. Journal of Food and Engineering, 92, 331-338. https://doi.org/10.1016/j.jfoodeng.2008.12.004

[16] Roberts, J.S., Tong, C.H. and Lund, D.B. (2002) Drying Kinetics and Time-Temperature Distribution of Pregelatinized Bread. Journal of Food Science, 67, 1080-1087. https://doi.org/10.1111/j.1365-2621.2002.tb09456.x 
[17] Rizvi, S.S.H. (1986) Thermodynamic Properties of Foods in Dehydration. In: Rao, M.A. and Rizvi, S.S.H., Eds., Engineering Properties of Foods, Marcel Dekker Inc., New York, 133-214.

[18] Rovedo, C.O., Suarez, C. and Viollaz, P.E. (1995) Drying of Foods: Evaluation of a Dryingmodel. Journal of Food Engineering, 26, 1-12. https://doi.org/10.1016/0260-8774(94)00037-A

[19] Crank, J. (1975) The Mathematics of Diffusion. 2nd Edition, Oxford University Press, London, UK, 69-88.

[20] Hassini, L., Azzouz, S., Peczalski, R. and Belghith, A. (2007) Estimation of Potato Moisture Diffusivity from Convective Drying Kinetics with Correction for Shrinkage. Journal of Food Engineering, 79, 47-56. https://doi.org/10.1016/j.jfoodeng.2006.01.025

[21] Jason, A.C. (1958) A Study of Evaporation and Diffusion Processes in the Drying of Fish Muscle. In: Fundamental Aspects of Dehydration of Foodstuffs, Society of Chemical Industry, London, 103-135.

[22] Villa-Corrales, L., Flores-Prieto, J.J., Xamán-Villaseñor, J.P. and García-Hernández, E. (2010) Numerical and Experimental Analysis of Heat and Moisture Transfer during Drying of Ataulfo Mango. Journal of Food Engineering, 98, 198-206. https://doi.org/10.1016/j.jfoodeng.2009.12.026

[23] Doymaz, I. (2007) Air-Drying Characteristics of Tomato. Journal of Food Engineering, 78,1291-1297. https://doi.org/10.1016/j.jfoodeng.2005.12.047

[24] Doymaz, I. (2005) Drying Behaviour of Green Beans. Journal of Food Engineering, 69, 161-165. https://doi.org/10.1016/j.jfoodeng.2004.08.009

[25] Kiranoudis, C.T., Maroulis, Z.B., Marinos-Kouris, D. and Saravacos, G.D. (1993) Estimation of the Effective Moisture Diffusivity from Drying Data. Application to Some Vegetables. In: ICEF6, Chiba, Japan. https://doi.org/10.1007/978-1-4615-2674-2_106

[26] Pavon-Melendez, G., Hernandez, J.A., Salgado, M.A. and Garcia, M.A. (2002) Dimensionnels Analysis of the Simultaneous Heat and Mass Transfer in Food Drying. Journal of Food Engineering, 51, 347-353. https://doi.org/10.1016/S0260-8774(01)00077-2

[27] Zogzas, N.P. and Maroulis, Z.B. (1996) Effective Moisture Diffusivity Estimation from Drying Data: A Comparison between Various Methods of Analysis. Drying Technology, 14, 1543-1573. https://doi.org/10.1080/07373939608917163

[28] Doymaz, I. (2005) Drying Characteristics and Kinetics of Ocra. Journal of Food Engineering, 69, 275-279. https://doi.org/10.1016/j.jfoodeng.2004.08.019

[29] Honoré, O.K., et al. (2014) Characterization of Okra Convective Drying. Influence of Maturity. Food and Nutrition Sciences, 5, 590-597.

https://doi.org/10.4236/fns.2014.56069 


\section{Nomenclature}

$D_{\text {eff: }}$ diffusion coefficient $\left(\mathrm{m}^{2} \cdot \mathrm{s}^{-1}\right)$

d: diameter $(\mathrm{m})$

$D_{0}$ : pre-exponential factor of the Arrhenius equation $\left(\mathrm{m}^{2} \cdot \mathrm{s}^{-1}\right)$

$E_{\mathrm{a}}$ : activation energy $\left(\mathrm{kJ} \cdot \mathrm{mol}^{-1}\right)$

$L$ : length $(\mathrm{m})$

m: mass $(\mathrm{kg})$

$R$ : constant perfect gases $\left(\mathrm{kJ} \cdot \mathrm{mol}^{-1} \cdot \mathrm{K}^{-1}\right)$

$r$ Ray $(\mathrm{m})$

$R^{2}$ : coefficient of determination

$R H$ : relative humidity of the air, \%

t. time (s)

T: temperature $\left({ }^{\circ} \mathrm{C}\right)$

$V$ : volume $\left(\mathrm{m}^{3}\right)$

$x$. Cartesian coordinate $(\mathrm{m})$

$X$ : water content $\left(\mathrm{kg}_{\mathrm{e}} \cdot \mathrm{kg}_{\mathrm{ms}}^{-1}\right)$

\section{Indices}

c: cylindre

cr: critical

d: diameter

ms: dry matter

eff: effective

eq: balance

f: final

0 : Initial $(t=0 \mathrm{~s})$

$\mathrm{L}$ : length

s: solid

e: water 